\title{
Pelatihan Bahasa Inggris Pekerja Migran Indonesia di Brunei Darussalam
}

\author{
DOI: https://doi.org/10.32509/abdimoestopo.v5i1.1759
}

\author{
Musa Maliki $^{\text {* }}$, Afrimadona ${ }^{2}$, Syifa Aulia Hasyyati ${ }^{3}$, Farrahdiba $^{4}$ \\ Universitas Pembangunan Nasional Veteran Jakarta \\ Jl. RS. Fatmawati Raya, Pd. Labu, Kec. Cilandak, Kota Depok, DKI Jakarta 12450, Indonesia \\ *Email Korespondensi: musamaliki@upnvj.ac.id
}

\begin{abstract}
This research is based on the study of international migration on Indonesian migrant workers (IMWs) living in Brunei Darussalam. The IMWs earn lower wages compared to their fellow Filipinos in the same job category because of their lack of English. The English skills become obstacles for the IMWs to earn better wages and be more competitive in the labor market. The goal of this research is to solve the problem of their lack of English skills. With our competency in International Relations (IR), especially focusing on international migration, we provided English language training for the IMWs through a collaboration with the Indonesian Embassy in Bandar Seri Begawan and the Open University. Using the participatory method and theoretical framework of globalization and migration, this research finds the needs of the IMWs to exercise intensively anytime, be it in class, at home, and at their workplace. Despite their difficulties in finding opportunities to practice their English, the IMWs needs to increase their motivation to learn and make time to develop their English skills whether in class or in everyday life.
\end{abstract}

Keywords: English Language, Migrant Worker, International Migration, Globalization

\begin{abstract}
Abstrak - Tulisan ini dilatarbelakangi studi migrasi internasional tentang Pekerja Migran Indonesia (PMI) yang tinggal di Brunei Darussalam. PMI memperoleh gaji yang lebih rendah daripada pekerja migran Filipina pada kategori pekerjaan yang sama karena lemahnya penguasaan bahasa Inggris mereka. Kemampuan bahasa Inggris menjadi hambatan bagi PMI untuk mendapatkan gaji yang lebih baik dan kompetitif di pasar tenaga kerja migran di Brunei Darussalam. Tujuan riset ini ialah untuk mencari solusi bagi lemahnya kemampuan bahasa Inggris PMI. Penulis yang berkompetensi dalam studi Hubungan Internasional, khususnya migrasi internasional, bekerja sama dengan KBRI Bandar Seri Begawan dan Universitas Terbuka cabang Brunei Darussalam untuk menyelenggarakan pelatihan bahasa Inggris. Melalui penggunaan metode partisipatoris dengan kerangka teoritis globalisasi dan konsep migrasi, penelitian ini menunjukkan perlunya PMI melatih kemampuan berbahasa Inggris secara intensif dimana pun, baik di kelas, rumah, dan tempat kerja. Meskipun sulit menemukan kesempatan untuk melatih kemampuan berbahasa Inggris, PMI perlu meningkatkan motivasi belajar dan meluangkan waktu untuk mengembangkan kemampuannya baik di kelas dan kehidupan seharihari.

Kata Kunci: Bahasa Inggris, Pekerja Migran, Migrasi Internasional, Globalisasi
\end{abstract}

\section{PENDAHULUAN}

Menurut Hout (1996), pada era globalisasi dunia terbagi menjadi pusat dan pinggiran dalam dimensi ekonomi-politik internasional. Sklair (1999) dan Wood (1997) berargumen 
bahwa proses globalisasi adalah proses pergerakan sistem kapitalisme global dari dunia Barat yang memaksa negara-negara di dunia untuk meningkatkan pertumbuhan ekonominya. Sistem kapitalisme global itulah yang memaksa proses migrasi internasional (Čiarnienė \& Kumpikaite, 2008). Hal itu berbeda dengan teori migrasi neo-klasik yang berpendapat bahwa migrasi terjadi karena adanya tekanan dari dalam negeri dan daya tarik luar negeri untuk hidup lebih layak. Migrasi adalah keterpaksaan domestik. Migrasi juga dikarenakan dorongan sosial imigran (De Haas, 2014, 2021).

Kebijakan migrasi di Indonesia sudah berlangsung sejak zaman Belanda dalam kebijakan politik etis van Deventer pada abad ke-19 yang digencarkan kembali pada masa Suharto saat negara Timur Tengah membutuhkan pekerja murah (Šumonja, 2021). Riset ini membahas Pekerja Migran Indonesia (PMI) di Brunei Darussalam. Berdasarkan data KBRI Bandar Seri Begawan (KBRI BSB) tahun 2018, PMI yang terdaftar di Brunei Darussalam sebanyak 28.830 orang yang terdiri dari pekerja perusahaan atau syarikat (toko, warung, konstruksi, dan profesional) berjumlah 14.165 orang, pekerja pada perorangan atau persendirian (disebut juga pekerja domestik) sebesar 7.661 orang, pekerja di pemerintahan sejumlah 95 orang, dan sisanya tidak terdapat data jelas terkait visa kerjanya. Indonesia merupakan negara pengirim tenaga kerja migran terbanyak ke Brunei Darussalam, diikuti oleh Filipina, Bangladesh, Malaysia, India, Pakistan dan lainnya. ${ }^{1}$

Berdasarkan temuan di lapangan, kemampuan berbahasa Inggris PMI berada di bawah pekerja Filipina. Kemampuan ini penting karena bahasa Inggris digunakan sehari-hari secara dominan, khususnya di dunia kerja dan memiliki nilai tambah dibandingkan bahasa Melayu. Oleh sebab itu, banyak PMI dipekerjakan sebagai pekerja berketerampilan rendah dan digaji rendah, meskipun lebih baik dibandingkan pekerja dari Bangladesh.

Berdasarkan penelusuran Penulis, bentuk pengabdian masyarakat di luar negeri pada era Covid-19 belum ada sehingga kami mengisi ruang kosong ini dan membantu Pemerintah Indonesia melaksanakan pelindungan dan pelayanan warga negara Indonesia (PMI) di luar negeri.

Sejauh ini, kegiatan pelatihan bahasa Inggris yang sudah dilakukan dan ditulis dilaksanakan di Indonesia dan bukan ditujukan kepada PMI, tetapi kepada anak-anak, mahasiswa, komunitas kepemudaan, dan guru bahasa Inggris. Riset-riset yang telah dilakukan di Indonesia dalam pelatihan bahasa Inggris diantaranya: Warman, Mardian, Suryani, Fista, and Irwan (2020), Ma'mun and Mariam (2021), Permata and Hadiani (2018), dan Hamid, Mannong, Hambali, and Sujariati (2021). Selain itu, pelatihan yang mirip dengan riset pengabdian masyarakat ini adalah kegiatan pelatihan 'English for Indonesia' yang diselenggarakan oleh British Chamber of Commerce in Indonesia dan Kedutaan Besar Inggris di Jakarta yang didukung oleh Kementerian Ketenagakerjaan RI. Program tersebut diharapkan dapat membekali PMI sebelum bekerja ke luar negeri karena disadari bahwa bahasa Inggris merupakan kelemahan utama PMI. Menteri Ketenagakerjaan Hanif Dhakiri juga mengajak investor dari Inggris maupun Eropa untuk meningkatkan kerja sama ekonomi dan peningkatan kualitas sumber daya manusia yang nantinya akan menciptakan tenaga kerja yang kompeten serta profesional dengan mengadakan berbagai pelatihan lainnya (Prasetyo, 2018).

Pengabdian Kegiatan Masyarakat (PKM) di Brunei Darussalam ini menyasar kebutuhan PMI yang ada di Brunei sehingga hasilnya diharapkan akan jauh berbeda dengan kegiatan-kegiatan sebelumnya yang dilakukan di Indonesia yang dilaksanakan di suatu komunitas, sekolah, universitas atau daerah tertentu. Tujuan utama PKM ini adalah memberi solusi bagi masalah kurangnya penguasaan bahasa Inggris PMI sehingga mereka dapat meningkatkan posisi tawar, bersaing dengan pekerja asing dari negara lain, terutama Filipina,

\footnotetext{
${ }^{1}$ Komposisi tenaga kerja asing di Brunei Darussalam cukup tinggi yaitu sekitar 28\% dari seluruh populasi Brunei sebesar 453.600 (2020). Pemerintah Brunei berupaya mengurangi ketergantungan terhadap tenaga kerja asing dan terkait itu, memberikan keutamaan kepada warga lokal untuk mengisi lowongan kerja yang ada sebelum dapat diisi tenaga kerja asing.
} 
dan pada akhirnya memperoleh remunerasi yang pantas dan dihargai atau tidak diremehkan baik oleh pekerja lain maupun majikannya.

\section{METODE PELAKSANAAN}

Metode yang digunakan adalah Participatory Action Research (PAR). Pain, Whitman, and Milledge (2011) memaparkan bahwa metode ini dilakukan oleh peneliti secara langsung di lapangan dari desain awal sampai dengan hasil akhir. Peneliti partisipatoris perlu memahami secara fenomenologis atau mendalam kondisi yang diteliti di semua level seperti kognitif, emosi, dan mental serta lingkungan sekitarnya. Oleh karena itu, subyek penelitian dapat dan harus menjadi peserta dalam mendefinisikan dan menafsirkan penelitian. Dalam hal ini, peneliti akan menggunakan metode ini dengan berpartisipasi dengan PMI.

Tata cara metode PAR ini dielaborasi dengan metode penulisan berdasarkan kompetensi penulis sebagai sarjana Hubungan Internasional. Dalam kerangka cara penulisannya, kami merujuk pada karya Simatupang, Silaen, Banjarnahor, and Sinaga (2021) dan Nurcandrani, Asriandhini, and Turistiati (2020). Terinspirasi dari karya mereka dan dalam kerangka karya mereka, pada kesempatan riset ini kami sebagai dosen Hubungan Internasional ingin melakukan kontribusi pada masa pandemi Covid-19 yaitu melakukan pengabdian masyarakat di Brunei Darussalam dalam membantu peningkatan kemampuan Bahasa Inggris PMI pada Januari-Juli 2021. Pada kurun waktu ini, Covid-19 di Brunei terkendali dan masih dapat melakukan pembelajaran tatap muka.

Kegiatan ini bermula dari hasil diskusi dan kepedulian dosen Hubungan Internasional dan diplomat di KBRI BSB terhadap upaya peningkatan pelayanan dan pelindungan WNI/PMI di Brunei Darussalam. Diskusi dan telaahan permasalahan PMI memunculkan gagasan kegiatan pelatihan bahasa Inggris untuk meningkatkan kemampuan PMI. Sebagai tindak lanjut, perumusan dan persiapan kegiatan dilakukan melalui pertemuan dengan Fungsi Sosial Budaya KBRI BSB sebanyak dua kali. Guna diseminasi informasi dan menjaring peserta pelatihan, Universitas Terbuka cabang Brunei Darussalam (UT) turut diundang berkolaborasi dalam kegiatan.

Selanjutnya, disepakati pemilihan lokasi kegiatan, perumusan kurikulum, rekrutmen pengajar dan peserta. KBRI BSB memfasilitasi sarana dan prasarana kegiatan pelatihan di ruang kelas aula dan ruang perpustakaan; UT mendiseminasikan informasi dan merekrut peserta pelatihan; dan kami mencari tenaga pengajar yang kompeten. Dalam hal ini kami berkolaborasi dengan Sdr. Lathief Ahmed Al-Mu'thie, mahasiswa UNISSA/mantan Ketua Umum PPI-BD 2020-2021, Dr. Wahyu Caesarendra, Assistant Professor Universiti Brunei Darussalam, dan Sdr. Arif Choirul Bashir, staf Administrasi KBRI BSB.

Pelaksanaan pelatihan bahasa Inggris dilakukan sebanyak sembilan belas kali pada periode Februari-Juli 2021. Kegiatan diawali dengan briefing pendahuluan pada 31 Januari 2021 yang diikuti dua puluh dua PMI yang mendaftar sebagai peserta pelatihan. Kami mengeksplorasi dan memetakan level kemampuan bahasa Inggris dengan tes sederhana secara kualitatif. Kami juga menjelaskan metode pelatihan bahasa Inggris yang berfokus pada percakapan dan membaca, karena kemampuan berbahasa Inggris yang dibutuhkan ialah kemampuan mempraktekkan dan memahami percakapan praktis.

Pada briefing disampaikan bahwa setiap pertemuan akan dimulai langsung dengan membaca dan berdialog. Para pengajar akan menyiapkan tema yang terkait dengan pekerjaan PMI dan memberi masukan dan arahan atas praktek berbahasa di kelas. Tema-tema lintas disiplin ilmu sosial seperti kebudayaan, sosiologi, dan antropologi menjadi pilihan. Dalam memilih tema ini, wawasan hubungan internasional diperlukan untuk memahami sensitivitas isu-isu politik tertentu yang baiknya dihindari. Jadwal pelatihan disepakati bersama antara peserta dan pengajar, yaitu setiap hari Minggu (hari libur pekerja) pukul 16.00 di KBRI BSB. 
Whatsapp Group juga disepakati dibentuk guna efektivitas berkomunikasi dan pelatihan secara kontinu meskipun di luar kelas.

Kurikulum pelatihan disusun meliputi seluruh komponen yaitu writing, listening, reading, dan speaking dengan titik berat pada percakapan dan membaca. Pengajaran bersifat fleksibel yaitu tidak menggunakan modul, tetapi memanfaatkan kompetensi masing-masing pengajar. Berdasarkan pembagian tugas, kami berfokus pada reading dan percakapan terkait dengan pronunciation; Dr. Wahyu Caesarendra dan Sdr. Lathief Ahmed Al-Mu'thie berfokus pada listening dan percakapan menggunakan metode creative learning melalui permainan, lagu, film, soal-soal TOEFL, dan sebagainya; dan Sdr. Arif Choirul Bashir berfokus pada writing, tata bahasa (grammar), dan percakapan.

Melalui metode partisipasi, pengajar dan peserta dapat berinteraksi secara intens dan terus berlatih berbahasa Inggris. Para peserta antusias dan senang menggunakan metode ini. Berdasarkan evaluasi, program kegiatan ini direncanakan akan berlanjut kembali dengan sejumlah perbaikan, yaitu disiplin waktu yang lebih ketat agar peserta lebih terlatih secara praktis berbahasa Inggris, bukan belajar teori. Bagi PMI di Brunei, practical skills berbahasa Inggris lebih diperlukan dari pada soft skills penguasaan pola berpikir teoritis.

\section{HASIL PENEMUAN DAN DISKUSI}

Hasil penemuan proses praktek pembelajaran ialah pertama, tingkat kehadiran peserta sangat baik pada dua setengah bulan pertama pelatihan, yaitu sekitar 18-20 orang per pertemuan. Selama periode tersebut, pengajaran dibagi menjadi dua kelas menggunakan ruang kelas aula dan ruang perpustakaan KBRI BSB. Namun setelah libur puasa dan lebaran (Mei 2021), jumlah peserta turun hingga delapan orang pada satu pertemuan menjadi satu kelas saja.

Kedua, berdasarkan evaluasi awal melalui wawancara setiap peserta, kami menilai secara umum tingkat kemampuan peserta bervariasi dari rendah sampai dengan sedang. Secara keseluruhan, asesmen awal kami menunjukkan seluruh peserta perlu meningkatkan kemampuan bahasa Inggrisnya. Hanya terdapat dua orang yang telah dapat berkomunikasi dua arah dengan bahasa Inggris karena mereka adalah skilled workers yang dituntut menggunakan bahasa Inggris dalam pekerjaannya sehari-hari. Sebagian besar peserta masih malu dan tidak percaya diri untuk berbahasa Inggris.

Setelah periode pelatihan berakhir, pada akhir pembelajaran, kembali dilakukan wawancara yang direkam sebagai evaluasi akhir yang kemudian dibandingkan dengan asesmen pada awal kegiatan. Berikut daftar peserta dan kemampuan akhirnya yang diukur secara kualitatif.

Tabel 1. Daftar Peserta Pelatihan Bahasa Inggris bagi Pekerja Migran Indonesia di Brunei Darussalam Bandar Seri Begawan, Januari-Juli 2021

\begin{tabular}{cllll}
\hline No & Nama & Pekerjaan & Aktif & \multicolumn{1}{c}{ Asesmen } \\
\hline 1 & Ade Fathurochman & $\begin{array}{l}\text { Pengelola saluran } \\
\text { air Brunei }\end{array}$ & Aktif & $\begin{array}{l}\text { Keberanian berbicara panjang } \\
\text { berkembang walaupun masih } \\
\text { bercampur dengan Bahasa Melayu. } \\
\text { Kemampuan percakapan di lingkungan } \\
\text { pekerjaan sudah berkembang. }\end{array}$ \\
2 & Muhamad Fauzi & $\begin{array}{l}\text { Karyawan Air } \\
\text { Sehat } \\
\text { Asisten rumah } \\
\text { tangga }\end{array}$ & $\begin{array}{l}\text { Kurang } \\
\text { aktif }\end{array}$ & Aktif \\
\hline
\end{tabular}




\begin{tabular}{|c|c|c|c|c|}
\hline & & & & $\begin{array}{l}\text { penguasaan tata bahasa, } \\
\text { memperbanyak kosa kata dan latihan. }\end{array}$ \\
\hline 4 & Ilan I. & Karyawan & $\begin{array}{l}\text { Kurang } \\
\text { aktif }\end{array}$ & \\
\hline 5 & Lia Chantia & Penjaga toko & Aktif & $\begin{array}{l}\text { Kemampuan percakapan berkembang, } \\
\text { tetapi perlu dilatih lebih lanjut. }\end{array}$ \\
\hline 6 & Khaled Hasan & Mahasiswa & Tidak & \\
\hline 7 & Alya N. & Mahasiswa UT & $\begin{array}{l}\text { Aktif } \\
\text { Aktif }\end{array}$ & $\begin{array}{l}\text { Sudah mempunyai keberanian } \\
\text { berbicara dan memakainya dalam } \\
\text { percakapan sederhana. Perlu motivasi } \\
\text { kuat untuk latihan secara mandiri. }\end{array}$ \\
\hline 8 & Uzlifatul Jannah & Mahasiswa & $\begin{array}{l}\text { Tidak } \\
\text { aktif }\end{array}$ & \\
\hline 9 & Zulfikar & Staf Gudang & Aktif & $\begin{array}{l}\text { Keberanian berbicara berkembang, } \\
\text { memiliki kosa kata yang banyak, } \\
\text { namun perlu meningkatkan } \\
\text { pemahaman tata bahasa. }\end{array}$ \\
\hline 10 & Siti Zainun Z. & $\begin{array}{l}\text { Asisten rumah } \\
\text { tangga }\end{array}$ & Aktif & $\begin{array}{l}\text { Keberanian berbicara panjang baik dan } \\
\text { berkembang dalam membaca. }\end{array}$ \\
\hline 11 & Nur Afiatul F. & Petugas katering & Aktif & $\begin{array}{l}\text { Mempunyai semangat dan kemampuan } \\
\text { membaca serta percakapan juga } \\
\text { meningkat. }\end{array}$ \\
\hline 12 & Oong Supono & Supervisor & $\begin{array}{l}\text { Tidak } \\
\text { aktif }\end{array}$ & \\
\hline 13 & Raga Sugeng S. & $\begin{array}{l}\text { Pekerja sedot } \\
\text { limbah }\end{array}$ & Aktif & $\begin{array}{l}\text { Walaupun pendiam, mempunyai } \\
\text { kemauan untuk berbicara dan } \\
\text { kemampuan membaca berkembang. }\end{array}$ \\
\hline 14 & Heppy Nova I K W & $\begin{array}{l}\text { Karyawan } \\
\text { restoran }\end{array}$ & Aktif & $\begin{array}{l}\text { Mempunyai keberanian berbicara dan } \\
\text { kemampuan percakapan bertambah. }\end{array}$ \\
\hline 15 & Devita Maharani & Kejar Paket C & $\begin{array}{l}\text { Tidak } \\
\text { aktif }\end{array}$ & \\
\hline 16 & Zahrul Gunawan & Pekerja workshop & Aktif & $\begin{array}{l}\text { Masih malu berbicara, tetapi } \\
\text { kemampuannya berkembang dan } \\
\text { berani tampil di depan kelas } \\
\text { melakukan percakapan. }\end{array}$ \\
\hline 17 & Sunaryo & Resepsonis & Aktif & $\begin{array}{l}\text { Kemampuan percakapan perlu } \\
\text { ditingkatkan, tetapi ada } \\
\text { perkembangannya dalam percakapan } \\
\text { maupun membaca. }\end{array}$ \\
\hline 18 & Sentara Harita & Penjual ikan & Aktif & $\begin{array}{l}\text { Mempunyai keberanian bicara, tapi } \\
\text { perlu dikembangkan lagi keaktifannya } \\
\text { dalam percakapan sehingga potensinya } \\
\text { dapat tergali secara maksimal. }\end{array}$ \\
\hline 19 & Ahmad & Kejar Paket C & $\begin{array}{l}\text { Tidak } \\
\text { aktif }\end{array}$ & \\
\hline 20 & Dana & Surveyor tanah & Aktif & $\begin{array}{l}\text { Kurang aktif dalam kelas, tapi jika } \\
\text { berbicara dapat mengungkapkan } \\
\text { ekspresi diri dalam bahasa Inggris. } \\
\text { Memerlukan motivasi kuat untuk } \\
\text { mengembangkan potensi. }\end{array}$ \\
\hline 21 & Faisal P. & $\begin{array}{l}\text { Karyawan } \\
\text { pembuatan pipa } \\
\text { kilang (pabrik) }\end{array}$ & Aktif & $\begin{array}{l}\text { Kemampuan berbahasa terus } \\
\text { berkembang dan terus dipakai dalam } \\
\text { pekerjaan. }\end{array}$ \\
\hline
\end{tabular}




\begin{tabular}{|c|c|c|c|c|}
\hline 22 & Hirjan & $\begin{array}{l}\text { Karyawan listrik } \\
\text { Brunei }\end{array}$ & Aktif & $\begin{array}{l}\text { Kemampuan percakapan bahasa } \\
\text { Inggris telah ada dan terus berkembang } \\
\text { sepanjang pembelajaran. Perlu training } \\
\text { yang lebih intens lagi agar maksimal. }\end{array}$ \\
\hline 23 & Ipan & Mekanik KIA & Aktif & $\begin{array}{l}\text { Kemampuan bahasanya sudah sangat } \\
\text { bagus dan terus berkembang sepanjang } \\
\text { pembelajaran. }\end{array}$ \\
\hline 24 & Herlan & Chef & Aktif & $\begin{array}{l}\text { Kemampuannya cukup bagus, tapi } \\
\text { perlu dilatih terus. }\end{array}$ \\
\hline 25 & Renggo & Mekanik & Aktif & $\begin{array}{l}\text { Kemampuan berbahasa Inggris baik } \\
\text { karena digunakan sehari-hari dalam } \\
\text { pekerjaan. Perlu meningkatkan } \\
\text { kemampuan percakapan yang panjang. }\end{array}$ \\
\hline
\end{tabular}

Keterangan: Aktif berarti menghadiri pertemuan 10 kali atau lebih (total 19 pertemuan)

Berdasarkan evaluasi akhir, terdapat peningkatan kemampuan berbahasa Inggris secara umum, tetapi kurang signifikan. Pada awal program sebelum libur puasa dan idul fitri, sebagian besar siswa hadir dan aktif di kelas, namun pada paruh kedua program tingkat kehadiran peserta menurun. Frekuensi pelatihan hanya dapat dilakukan seminggu sekali karena kesibukan PMI pun juga kurang memadai. Meskipun hal ini telah diantisipasi dengan memotivasi peserta berbahasa Inggris di luar kelas, pada prakteknya hal ini sulit dilakukan. Hal positif ialah adanya kemajuan atas keberanian peserta untuk berbicara dalam bahasa Inggris yang bercampur dengan bahasa Melayu. Hal ini kami pandang sangat baik untuk mengembangkan kemampuan peserta ke depan.

Secara lebih detail, perkembangan signifikan dicapai oleh Ade, Faisal, Ipan, dan Renggo yang pada awalnya kurang lancar berbicara, membaca, dan menulis dalam bahasa Inggris. Setelah pelatihan, mereka dapat bercerita tentang dirinya, pekerjaannya, dan kesehariannya dalam bahasa Inggris dengan para pengajar. Sebaliknya, ada pula peserta seperti Nana (Samaran) dan Dana (Samaran) yang memang membutuhkan proses lebih lama untuk dapat lancar berkomunikasi dalam bahasa Inggris dan masih pada level menjawab pertanyaan bahasa Inggris secara singkat.

Heppy, Sunaryo, Herlan, dan Sentara mengalami kesulitan mengatur waktu sehingga tingkat kehadiran di kelas rendah dan capaian belajarnya kurang maksimal, meskipun memiliki potensi berkembang secara pesat. Pada akhir program, kemampuan mereka berada pada level yang baik seperti Ade, Faisal, Ipan, dan Renggo. Lia dan Zulfikar sangat rajin datang sehingga perkembangannya signifikan, yakni semakin berani berbicara dan menjawab pertanyaanpertanyaan sederhana. Lia menyatakan kurang adanya kesempatan mempraktekkan bahasa Inggris di tempat kerjanya karena pelanggan toko yang datang sebagian besar berbahasa Melayu. Gambar 1 di bawah ini adalah foto para peserta aktif dalam proses belajar di ruang perpustakaan KBRI BSB. 


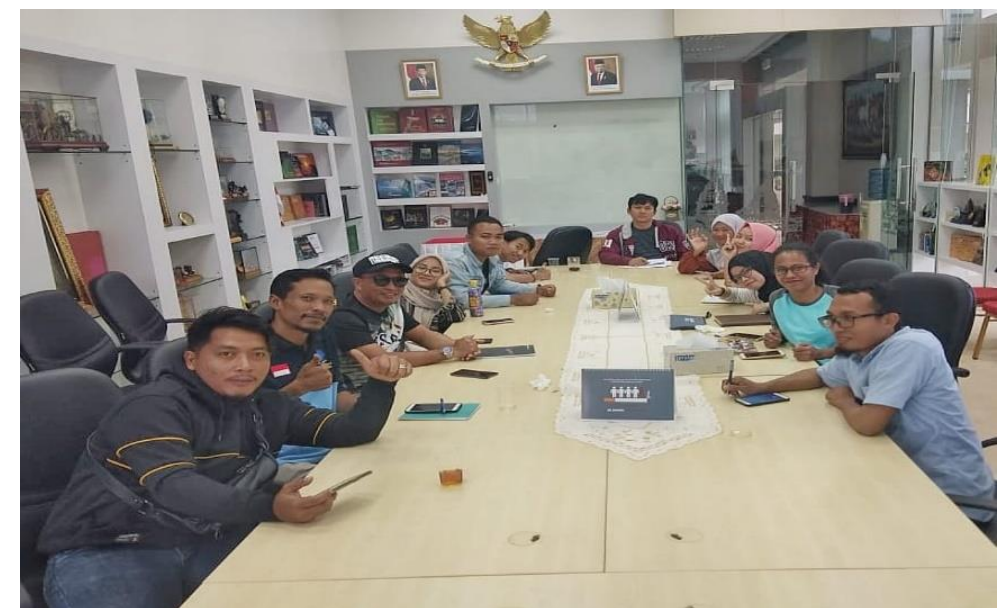

Gambar 1: Peserta pelatihan bahasa Inggris di Perpustakaan KBRI BSB (Sumber: Dokumentasi Peneliti)

Ketiga, pembentukan saluran komunikasi Whatsapp Group sangat membantu untuk berbagi informasi dan ilmu. Dalam Whatsapp Group, peserta diajak aktif untuk berkomunikasi dengan bahasa Inggris dan pertanyaan serta pertukaran ilmu juga dilaksanakan melalui grup sehingga mendukung kegiatan pelatihan secara virtual. Whatsapp Group juga memberi peluang bagi kami semua untuk mengkonfirmasi berbagai hal, khususnya jika saat pengajaran terdapat kekurangan atau kesalahan untuk langsung dibahas. Jadi intensitas percakapan di Whatsapp Group memberikan ruang untuk belajar menulis dalam bahasa Inggris.

Keempat, pengetahuan tidak hanya didapatkan satu arah, melainkan dua arah. Para peserta memiliki banyak pengalaman dalam pekerjaannya yang dapat dibagikan kepada pengajar maupun peserta lainnya. Dengan demikian, tidak hanya peningkatan kemampuan dan keberanian berbahasa Inggris, namun juga peningkatan wawasan para peserta. Hal inilah yang secara teoritis membuat globalisasi sosial yang dikatakan Haas di atas menjadi penting. Bahasa Inggris menjadi media penting untuk mempertemukan komunitas sosial Indonesia agar bisa masuk ke dalam sistem kerja global yang lebih kompetitif. Sarjana Hubungan Internasional seperti kami memberikan ruang interaksi sosial global dan mengefektifkan proses migrasi internasional melalui bahasa Inggris yang isinya diksi-diksi terkait hubungan internasional.

Argumen awal pelaksanaan riset ini dibangun dari globalisasi yang tidak dapat dihindari dan menuntut semua orang dapat saling berkomunikasi. Dengan adanya perbedaan akar budaya dan bahasa, kita harus menguasai media yang dapat menjembatani komunikasi dengan bangsa lain. Bangsa Indonesia tidak memiliki keuntungan historis jejak imperialisme masa lalu negara Anglo-Saxon yaitu kemampuan bahasa Inggris yang menjadi bahasa pengantar global. Oleh sebab itu, diperlukan upaya lebih untuk menguasai bahasa ini yang menjadi prasyarat penting berkomunikasi dan berjejaring lintas batas negara. Tanpa penguasaan bahasa ini (ataupun bahasa asing lainnya), kemampuan untuk menangkap peluang kerja sama atau bekerja di tempat yang lebih baik, berkualitas, dan menjanjikan, akan lebih sulit. Bagi PMI, ketidakmampuan berbahasa Inggris membuat mereka terus terperangkap dalam kondisi yang sulit naik kelas di sistem kerja internasional.

Lingkaran setan inilah yang ingin diputus oleh tim pengabdi. Kesibukan PMI baik yang low-skilled maupun high-skilled untuk bekerja seringkali membuat mereka kehabisan waktu untuk mengasah kemampuan berbahasa Inggris yang sebenarnya bisa membuat mereka lebih dihargai secara ekonomi dan sosial. PMI, khususnya yang berpenghasilan rendah, juga menghadapi kendala waktu dan biaya untuk mengikuti kursus bahasa professional, meskipun disadari peningkatan kapasitas ini perlu untuk meraih sukses. Karenanya, kegiatan pengabdian 
kepada masyarakat ini menjadi sangat penting dilakukan sebagai upaya membantu peningkatan kemampuan berbahasa Inggris PMI.

Pengabdian yang dilaksanakan di BSB, Brunei ini tergolong unik karena merupakan satu dari sedikit pengabdian yang diselenggarakan di luar negeri. Umumnya, pengabdian kepada masyarakat diselenggarakan di dalam negeri sendiri karena paling tidak dua alasan: keterbatasan dana dan corporate social responsibility kampus. Namun, pandangan ini tentu juga memiliki kelemahan, yakni kalangan PMI seperti tak tersentuh, sehingga kami mengisi kekosongan itu.

\section{SIMPULAN}

Kegiatan pelatihan bahasa Inggris merupakan solusi dari permasalahan PMI dalam upaya meningkatkan kemampuannya di Brunei Darussalam. Era globalisasi menciptakan kondisi dan peluang bagi warga Indonesia untuk bekerja keluar negeri. Pelatihan bersifat partisipatoris ini memberi masukan kepada peneliti bahwa persoalan PMI tidak dapat dipahami hanya pada level esensi globalisasi ekonomi, tetapi globalisasi sosial juga. Bahasa sebagai media memfasilitasi komunikasi antarsubjek pelaku ekonomi dan sosial. Bahasa Inggris sebagai lingua franca di banyak negara termasuk Brunei Darussalam menjadi prasyarat penting untuk bisa menangkap peluang globalisasi ekonomi yang lebih baik.

Dalam upaya memahami para partisipan inilah tim pengabdi juga mencoba mempelajari kompleksitas pribadi dan perilaku PMI. Hasil observasi terhadap karakteristik ini memberikan informasi berharga bagi tim pengabdi mengenai faktor-faktor yang berpotensi mempengaruhi performa mereka dalam belajar. Hasil observasi tim pengabdi memperlihatkan bahwa banyak tantangan dalam capaian target pembelajaran seperti kondisi waktu luang yang sempit, frekuensi pertemuan yang sedikit, dan tantangan menyeimbangkan jadwal pekerjaan dan jadwal belajar. Hal lain yang tidak secara langsung berpengaruh tetapi sangat signifikan menopang pembelajaran ialah kondisi keluarga, kemudahan mobilitas (transportasi), motivasi belajar, dan harapan orang tua di Indonesia. Kompleksitas latar belakang dan kondisi personalsosial dari para partisipan sangat mempengaruhi motivasi dan performa mereka belajar bahasa Inggris.

Observasi tim pengabdi terhadap keseluruhan proses PKM ini pada akhirnya juga menunjukkan bahwa kondisi pekerjaan adalah faktor yang paling berperan dalam capaian pembelajaran individu. Di satu sisi, mereka yang memiliki pekerjaan low-skilled sangat termotivasi untuk menguasai bahasa Inggris demi memperluas peluang mereka untuk mendapatkan pekerjaan yang lebih baik. Namun di sisi lain, mereka juga terperangkap dengan berbagai macam tantangan tadi, khususnya ketidakpastian jadwal pekerjaan yang amat tergantung instruksi majikan. Inilah yang seringkali mempersulit upaya mereka mencapai target pembelajaran dengan baik.

\section{Ucapan Terima Kasih}

Kami mengucapkan terima kasih kepada Duta Besar RI untuk Brunei Darussalam Dr. Sujatmiko beserta jajaran di KBRI Bandar Seri Begawan, khususnya para pejabat Fungsi Sosial dan Budaya KBRI BSB selama kegiatan ini dilaksanakan yaitu Bapak Conakry Marsono Yamtomo dan Ibu Endang Dewi Mardeyani selaku Koordinator Fungsi serta Bapak Wahyu Prabowo dan Ibu Asri Okina Gunanti sebagai Pelaksana Fungsi, yang memungkinkan pelaksanaan kegiatan ini.

Kami juga mengucapkan terima kasih sebesar-besarnya kepada Dr. Wahyu Caesarendra, Assistant Professor Universiti Brunei Darussalam; Sdr. Arif Choirul Bashir, staf Administrasi KBRI BSB; dan Sdr. Lathief Ahmed Al-Mu'thie, mahasiswa UNISSA/mantan 
Ketua Umum PPI-BD 2020-2021 atas kesediaan mereka membantu proses berjalannya pengabdian ini, khususnya dalam pengajaran. Ucapan terima kasih turut kami sampaikan kepada Sdr. Aris Purwanto sebagai Koordinator Universitas Terbuka di Brunei Darussalam yang membantu observasi peserta pelatihan bahasa Inggris dan penyebaran informasi tentang program pengabdian ini sehingga dapat terlaksana dengan lancar.

\section{Daftar Pustaka}

Čiarnienè, R., \& Kumpikaitè, V. (2008). The impact of globalization on migration processes. Socialiniai tyrimai(3), 42-48. $\quad$ Retrieved from https://etalpykla.lituanistikadb.lt/object/LT-LDB-0001:J.04 2008 1367164208598/

De Haas, H. (2014). What drives human migration. Retrieved from Oxford: International Migration Institute: https://heindehaas.files.wordpress.com/2015/05/de-haas-2014what-drives-human-migration.pdf

de Haas, H. (2021). A theory of migration: the aspirations-capabilities framework. Comparative Migration Studies, 9(1), 8. doi:10.1186/s40878-020-00210-4

Hamid, S. M., Mannong, A. B. M., Hambali, U., \& Sujariati, S. (2021). Pelatihan Pembelajaran Bahasa Inggris Dasar Bagi Pemuda Gentung Community Melalui Media Presentasi Prezi. Jurnal Abdimasa Pengabdian Masyarakat, 4(2), 90-98. Retrieved from https://unimuda.e-journal.id/jurnalabdimasa/article/view/863/657

Hout, W. (1996). Globalization, regionalization and regionalism: A survey of contemporary literature. Acta Politica, 31(2), 164-181. Retrieved from https://hdl.handle.net/2066/190409

Ma'mun, N., \& Mariam, S. (2021). Pelatihan kompetensi literasi digital bagi guru bahasa inggris berbasis e-learning moodle. Rengganis Jurnal Pengabdian Masyarakat, 1(1), 69-79. Retrieved from https://doi.org/10.29303/rengganis.v1i1.15

Nurcandrani, P. S., Asriandhini, B., \& Turistiati, A. T. (2020). Pelatihan Public Speaking untuk Membangun Kepercayaan Diri dan Keterampilan Berbicara pada Anak-Anak di Sanggar Ar-Rosyid Purwokerto. ABDI MOESTOPO: Jurnal Pengabdian Pada Masyarakat, 3(01), 27-32. doi: https://doi.org/10.32509/am.v3i01.979

Pain, R., Whitman, G., \& Milledge, D. (2011). Participatory action research toolkit. In: Durham: Durham University Press.

Permata, N. N., \& Hadiani, D. (2018). Pelatihan bahasa Inggris dasar dalam upaya peningkatan kemampuan mahasiswa bidikmisi polman Bandung. Jurnal Pengabdian Kepada Masyarakat, $\quad 2(4), \quad 338-341 . \quad$ Retrieved from http://journal.unpad.ac.id/pkm/article/view/19781

Prasetyo, A. (2018). Indonesia-Inggris kerjasama pelatihan bahasa Inggris bagi para pekerja. Media Indonesia. Retrieved from https://mediaindonesia.com/ekonomi/185776/indonesia-inggris-kerja-sama-pelatihanbahasa-inggris-bagi-para-pekerja

Simatupang, L. L., Silaen, H., Banjarnahor, S., \& Sinaga, R. M. (2021). Pelaksanaan Rapid Test Antigen Covid-19 Kepada Generasi Muda Kota Medan dan Deli Serdang. ABDI MOESTOPO: Jurnal Pengabdian Pada Masyarakat, 4(02), 73-79. doi: https://doi.org/10.32509/abdimoestopo.v4i02.1447

Sklair, L. (1999). Competing conceptions of globalization. Journal of World-Systems Research, 142-163. doi:https://doi.org/10.5195/jwsr.1999.140

Šumonja, M. (2021). Neoliberalism is not dead - On political implications of Covid-19. Capital \& Class, 45(2), 215-227. doi:10.1177/0309816820982381

Warman, J. S., Mardian, V., Suryani, L., Fista, F. R., \& Irwan, I. (2020). Program pelatihan penigkatan kemampuan bahasa inggris anak-anak panti asuhan melalui pemberdayaan 
mahasiswa. Dinamisia : Jurnal Pengabdian Kepada Masyarakat, 3(2), 280-285. doi:10.31849/dinamisia.v3i2.3304

Wood, E. M. (1997). Modernity, postmodernity or capitalism? Review of International Political Economy, 4(3), 539-560. doi:https://doi.org/10.1080/096922997347742 